NOTAS

\title{
A LUBBER GRASSHOPPER, XYLEUS DISCOIDEUS ROSULENTUS (STÅL, 1878) (ORTHOPTERA: ROMALEIDAE: ROMALEINAE) IN THE DOMINICAN REPUBLIC
}

\author{
Daniel E. Perez-Gelabert ${ }^{1}$, Ruth H. Bastardo ${ }^{2}$ y Brígido Hierro ${ }^{3}$ \\ ${ }^{1}$ Department of Entomology, U. S. National Museum of Natural History, Smithsonian \\ Institution, P.O. Box 37012, Washington, DC 20013-7012, USA. perezd@si.edu \\ ${ }^{2}$ Instituto de Investigaciones Botánicas y Zoológicas, Universidad Autónoma de Santo \\ Domingo, Santo Domingo, República Dominicana.r_bastardo@hotmail.com \\ ${ }^{3}$ Departamento de Vida Silvestre, Ministerio de Medio Ambiente y Recursos Naturales, \\ Santo Domingo, República Dominicana.b_hierro@hotmail.com
}

\section{ABSTRACT}

The grasshopper Xyleus discoideus rosulentus (Stål, 1878) is reported for the first time in the Dominican Republic. This is the first record of the family Romaleidae in the Greater Antilles. The record probably represents an unintended introduction of this species from its natural range in Central America and Colombia.

Key words: romaleids, introduced species, Hispaniola, Greater Antilles.

\section{RESUMEN}

Se reporta el saltamontes Xyleus discoideus rosulentus (Stål, 1878) por primera vez en la República Dominicana. Este es el primer registro de la familia Romaleidae en las Antillas Mayores. El registro de esta especie en República Dominicana probablemente representa una introducción accidental desde su rango natural en América Central y Colombia.

Palabras clave: romaleidos, especies introducidas, Hispaniola, Antillas Mayores

\section{INTRODUCTION}

Romaleidae is a large family of mostly South American grasshoppers that includes 103 genera and over 500 species (Otte, 1995). They are considered an autochthonous South American family that has diversified to occupy many habitats, from semi-arid conditions to the tropical rain forest. From their center of origin in southern temperate and subtropical South America, romaleids have spread north into Central America, Mexico and the southern Nearctic region (Carbonell, 1977). Only seven genera and 27 species are found in the southern part of the Nearctic region, while 78 species are found in Central America. The only records of this family from the West Indian islands are of the very large Tropidacris cristata cristata (Linnaeus, 1758), which occurs in the islands of St. Vincent and Grenada, as well as the continental islands of Tobago and Trinidad (Carbonell, 1986).

Xyleus Gistel, 1848 was recently revised by Carbonell (2004), and 16 species were recognized as valid. Most of these grasshoppers have a similar superficial appearance, and reliable identification appears in many cases to require examination of the internal male genitalia. These are large and robust grasshoppers $(30-70 \mathrm{~mm}$ ) with full wings, although they are weak fliers. External body colors in adults are always varying shades of fuscous and dull brown with some large black blotches mainly on the tegminae, while some individuals may also have small areas of dull green color mainly around the pronotum. The membranous wings are brightly colored in shades of reddish in all species. Also they characteristically have a raised pronotal crest marked with deep transverse sulci. The genus presents a discontinuous distribution, having a northern component that extends from southeastern Mexico through Central America and northeastern South America, separated by the Amazon basin 
from the main group of species which is found south of the equator through most of South America east of the Andes as far south as Montevideo (Carbonell, 2004). Some of these species have a wide geographic distribution, while others are known only from a few specimens collected at very restricted localities. Species of Xyleus inhabit dry forests and savanna, places with scattered trees or the edges and more open parts of forests. In their food habits these grasshoppers are polyphagous but are reported as not having much economic importance. Xyleus discoideus (Serville, 1831) is the species that makes up the northern group, being distributed as different subspecies from Mexico to Venezuela. Carbonell (2004) divided $X$. discoideus into five very morphologically uniform subspecies (X.d. discoideus, X. d. Angulatus, X.d. venezuelae, X. d. rosulentus, and X. d. mexicanus). These subspecies are distinguished mainly by the configuration of venation at the tegminal apex, shape of the prosternal tubercle and the shape of the cingulum and of the apical endophallic valves in the male genitalia.

\section{DISCOVERY OF XYLEUS IN THE DOMINICAN REPUBLIC}

A group of unknown green grasshopper nymphs in several stages before maturity and a single variegated brown adult male were collected in November 2007 among the herbaceous vegetation at the edge of a disturbed forest in Engombe, Santo Domingo. Because of their characteristically raised pronotal carina, these juveniles were immediately recognized as different from any of the local species. Although we collected around 30 juveniles, about half were released; 14 were actually kept and taken to the laboratory. The juveniles were kept alive at the Instituto de Investigaciones Botánicas y Zoológicas (IIBZ) of Universidad Autónoma de Santo Domingo (UASD), and from that group a total of two males and four females were successfully raised to adulthood in a 10 gallon fish tank where they were fed a variety of foods. These individuals lived for around 5 months and were later killed and dry-mounted on pins. We had briefly visited this same locality (Palacio de Engombe) during the summer of 2006 without seeing this species. This altered secondary forest is located on the western fringes of the city of Santo Domingo and is slowly being pushed back by the construction of new houses. The vegetation of the site can be characterized as being a varied combination of grasses, mixed weeds and low bushes at the edge of more densely growing secondary forest with trees that shade most of the undergrowth. Grasshoppers of this species were not collected on two other subsequent visits to the same site during the warm months of the year (June and August 2008). Two juveniles (male and female) were found at the same spot on December 28, 2008. Although the species seems to be established at the site, at times it becomes uncommon enough to be easily missed if not carefully searched among the undergrowth. It is clear that a more precise understanding of the density and frequency of these grasshoppers will require a more thorough collecting effort at different times of the year, also extending the search to several other probable sites around the area where they have been found.

The single adult specimen collected initially was brought to the U. S. National Museum of Natural History (USNM), Smithsonian Institution, Washington, DC and compared to specimens in the Orthoptera collection housed at Beltsville, MD. This male was later dissected and its genitalia compared to drawings given by Carbonell (2004) for each subspecies. It was tentatively identified as $X$. discoideus rosulentus (Stål, 1878). This identification was later confirmed by professor Carlos Carbonell (Universidad de la República, Uruguay) through examination of an adult male specimen sent to him. The known natural distribution range of $X$. discoideus rosulentus is Costa Rica, Panama and Colombia. The accidental discovery at a single location of this rather conspicuous species, makes us believe that the presence of $X$. discoideus rosulentus in the Dominican Republic is probably due to a rather recent accidental introduction. The first author has been sampling and studying the Hispaniolan and other Antillean grasshoppers for the last 20 years. This is the first time that a romaleid grasshopper has been collected in Hispaniola and the Greater Antilles.

Material examined. 1 male, DOMINICAN REPUBLIC, Santo Domingo Oeste, Palacios de Engombe, secondary vegetation, $18^{\circ} 27.038^{\prime} \mathrm{N} 69^{\circ} 59.800^{\prime} \mathrm{W}$, 9.xi.2007, D. Perez, R. Bastardo, B. Hierro, S. Medrano, A. Hilario, R. Rodríguez. Deposited in the U. S. National Museum of Natural History (USNM) collection. 1 male 4 females, same collecting data, taken as juveniles and later raised to adults in the laboratory. Deposited in the Instituto de Investigaciones Botánicas y Zoológicas (IIBZ and USNM). 1 male, same collecting data, kept in collection of the Universidad de la República, Uruguay. 


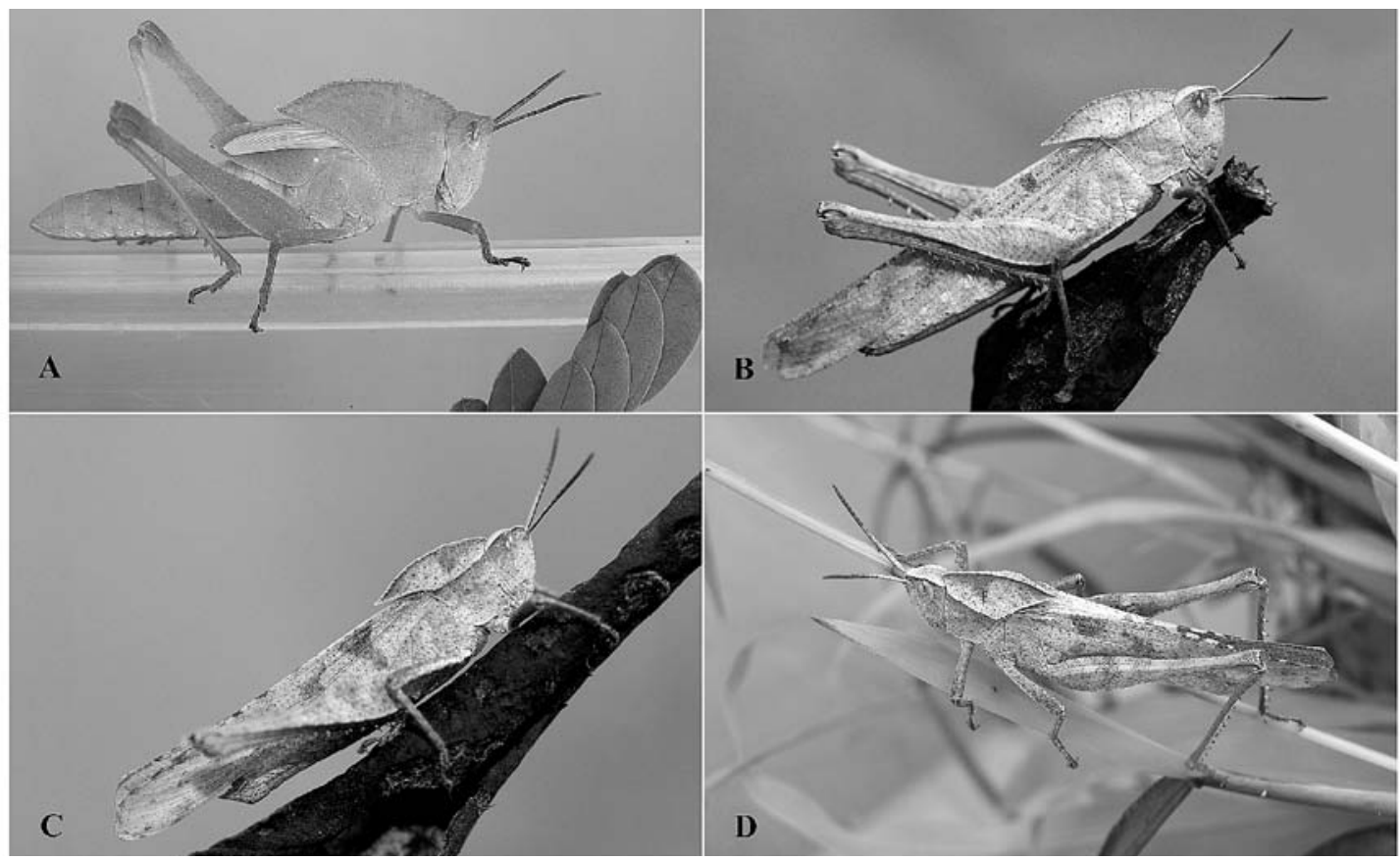

Figure 1. Photos of Xyleus discoideus rosulentus (Stål) collected in Santo Domingo and reared in the laboratory (A. Female nymph; B. Adult female; C. Adult male; D. Adult male).

Remarks. The fauna of acridomorph grasshoppers in the West Indies (Bahamas, Greater Antilles and Lesser Antilles) includes 79 reported species in the families Acrididae (58 species), Pyrgomorphidae ( 2 species, in Hispaniola), Episactidae (11 species, in Hispaniola), Eumastacidae (6 species, in Cuba) and Romaleidae ( 2 species). From Hispaniola a total of 38 grasshopper species are recorded (PerezGelabert, 2008), although several new species of endemic Acrididae await description. Most acridomorph grasshoppers in Hispaniola are endemic to the island ( 29 of 38 species, $76.3 \%$ and 27 of 38 species $(71.1 \%)$ have reduced wings or no wings at all. Until now Melanoplus sanguinipes (F.) (Acrididae: Melanoplinae) was the only grasshopper known to have been introduced to Hispaniola (Perez-Gelabert \& Otte, 2003). This species is an important pest of crops and pastures in the United States and Canada (Pfadt, 1994). Fortunately, in the Dominican Republic M. sanguinipes seems to be restricted to cold high valleys of the Cordillera Central where they appear to eat mostly weedy vegetation.

It remains to be seen if any significant ecological changes will occur due to the presence of $X$. discoideus rosulentus and whether it will spread and become a common feature of the weedy and open vegetation habitats in southern Dominican Republic. It may be of interest to monitor populations of this grasshopper in order to document any effects on the local habitats and whether through competition they cause changes on the populations of native grasshoppers. At least it is a good thing that although polyphagous Xyleus grasshoppers are not considered to pose any threat to agriculture.

\section{ACKNOWLEDGMENTS}

We thank Dominican biologists and friends Sardis Medrano, Alexis Hilario and Rosa Rodríguez for their assistance with the fieldwork leading to the discovery of this species. David Nickle (Systematic Entomology Lab, USDA) facilitated our examination of specimens in the USNM Orthoptera collection located at Beltsville, MD. Carlos Carbonell (Universidad de la República, Uruguay) expertly confirmed our identification through the study of one adult male specimen sent to him for examination. Lucrecia Rodríguez (Systematic Entomology Lab, Washington, DC) graciously used her computer expertise to produce the plate. Robert Kula (Systematic Entomology Lab, Washington, DC) and Hugh Rowell (Zoologisches Institut, Universitaet Basel) made helpful corrections to our manuscript. 


\section{LITERATURE CITED}

Carbonell, C. S. 1977. Origin, evolution, and distribution of the Neotropical acridomorph fauna (Orthoptera): a preliminary hypothesis. Revista de la Sociedad Entomológica Argentina, 36: 153175 .

Carbonell, C. S. 1986. Revision of the neotropical genus Tropidacris (Orthoptera, Acridoidea, Romaleidae, Romaleinae). Proceedings of the Academy of Natural Sciences of Philadelphia, 138: 366-402.

Carbonell, C. S. 2004. The genus Xyleus Gistel 1848 (Acridoidea, Romaleidae, Romaleinae). Journal of Orthoptera Research, 13: 63-133.

Otte, D. 1995. Orthoptera Species File 4. Acridomorpha. The Orthopterists' Society and The Academy of Natural Sciences of Philadelphia Philadelphia, PA, 518 pp.

Perez-Gelabert, D. E. 2008. Arthropods of Hispaniola (Dominican Republic and Haiti): a checklist and bibliography. Zootaxa, 1831: 1-530.

Perez-Gelabert, D. E. \& Otte, D. 2003. Melanoplus sanguinipes (Fabricius) (Orthoptera: Acrididae: Melanoplinae), a pest grasshopper introduced to Dominican Republic, Hispaniola. Transactions of the American Entomological Society, 129: 497-502.

Pfadt, R. 1994. Migratory grasshopper Melanoplus sanguinipes (Fabricius). Wyoming Agricultural Experiment Station Bulletin 912, Species Fact Sheet. www.sdvc.uwyo.edu/grasshopper/mesa.htm. 